\title{
PROFIL USAHA SELAI NANAS “CAP BURUNG MALEO” UD ASLI TOTABUAN DI KELURAHAN MOTOBOI KECIL KOTA KOTAMOBAGU.
}

\author{
Dini Budihastuti \\ Theodora M. Katiandagho \\ Noortje M. Benu
}

\begin{abstract}
The purpose of this research is to describe the Profile of Pineapple Jam Business "Cap Burung Maleo" UD Asli Totabuan especially in the raw materials supplying aspect, management, marketing, also the profits of pineapple jam production. This research has been carried out for three months, from April until June 2016. Data used in this research is primary data that collected from UD Asli Totabuan and primary data obtained from interview with the Owner of UD Asli Totabuan. Analysis used in this research is Profits analysis, revenue, Break Even Point (BEP), to find out the profits and revenue of UD Asli Totabuan. Based on the research result, UD Totabuan in the pineapple jam production only producing once or twice in a year, on the pineapple harvest season and when there is no price spike, raw materials obtained from farmers in the West Passi and Lobong. The Industry management of UD Totabuan is simple doesn't use the management functions like planning, organizing, actuating, and controlling. The Marketing channels of UD Asli Totabuan is two which from Producer to Producer and Producer to Retailer, Retailer to consumer. The profits of Pineapple jam business by UD Totabuan Cap Burung Maleo for March 2016 is Rp. 9.625.828, *ls*
\end{abstract}

Keywords: Pineapple Jam, “Cap Burung Maleo”, Motoboi Kecil Village, Kotamobagu City

\begin{abstract}
ABSTRAK
Penelitian ini bertujuan untuk mendeskripsikan profil usaha selai nanas Cap Burung Maleo UD Asli Totabuan terlebih khusus untuk aspek pengadaan bahan baku, manajemen, pemasaran, serta laba yang diperoleh dalam memproduksi selai nanas. Penelitian ini dilaksanakan selama tiga bulan, sejak bulan April 2016 sampai pada bulan Juni 2016. Data yang digunakan dalam penelitian ini adalah data primer yaitu data-data yang diperoleh dari UD Asli Totabuan dan data primer yaitu data yang diambil melalui wawancara langsung kepada pemilik UD Asli Totabuan. Analisis data yang digunakan dalam penelitian ini adalah dengan menggunakan analisis keuntungan, penerimaan, Break Event Point (BEP) untuk mengetahui berapa keuntungan yang diperoleh UD Totabuan dan juga berapa penerimaannya. Berdasarkan hasil penelitian yang dilaksanakan di UD Totabuan, dapat di simpulkan bahwa dalam melakukan produksi selai nanas UD Totabuan, hanya melakukan proses produksi satu sampai dua kali dalam satu tahun yaitu pada saat musim panen nanas dan juga pada saat tidak terjadinya kelonjakan harga, bahan baku yang digunakan yaitu buah nanas yang diperoleh dari petani yang ada di Passi Barat dan Lobong. Manajemen industri UD Totabuan sangat sederhana, tidak menggunakan fungsi Manajemen yaitu perencanaan, organizing, actuating, controlling. Saluran pemasaran yang dilalui UD Asli Totabuan meliputi dua saluran yaitu Produsen ke konsumen dan Produsen ke Pedagang Pengecer ke Konsumen. Laba yang diperoleh usaha selai Nanas UD Totabuan Cap Burung Maleo untuk bulan Maret 2016 sebesar Rp. 9.625.828
\end{abstract}

Kata kunci: Selai Nanas, “Cap Burung Maleo”, Kelurahan Motoboi Kecil, Kota Kotamobagu 


\section{PENDAHULUAN}

\section{Latar Belakang}

Nanas (Ananas comosus (L.) Merr.) merupakan salah satu tanaman buah yang banyak dibudidayakan di daerah tropis dan sub tropis. Buah ini berasal dari Brazil, Bolivia, dan Paraguay. Tumbuhan ini termasuk dalam familia nanas-nanasan (Family Bromeliaceae). Perawakan (Habitus), tumbuhannya rendah, herba (menahun) dengan 30 atau lebih daun yang panjang, berujung tajam, tersusun dalam bentuk roset mengelilingi batang yang tebal. Buah dengan tekstur kulit bersisik ini menjadi salah satu buah yang sangat segar saat dikonsumsi pada cuaca yang sangat panas atau terik, karena buah ini memiliki kandungan air yang cukup melimpah pada daging buahnya. Buah yang berwarna kuning cerah yang mengandung vitamin, mineral, antioksidan, dan enzim yang bersifat melancarkan pencernaan, meredakan asam lambung atau maag (Harta, 2012).

Buah nanas juga mengandung 52 kalori; 0,4 g protein; 0,2 g lemak; 13,7 g kabohidrat; $16 \mathrm{mg}$ kalsium; $11 \mathrm{mg}$ fosfor; $0,3 \mathrm{~g}$ besi; 0,008 mg Vit B; 85,3 g air serta $53 \%$ bagian yang dapat dimakan dalam $100 \mathrm{~g}$ buah nanas.Buah nanas dalam kondisi segar hanya mempunyai umur simpan antara 1 sampai 7 hari (Lies, 2001).

Pada saat terjadi panen, jumlah produksi buah nanas sangat melimpah namun tidak sebanding dengan tingkat konsumsinya sehingga harga jual dipasaran sangat murah. Untuk mencegah tidak termanfaatkannya buah nanas pada saat jumlahnya sangat melimpah perlu dilakukan usaha untuk memperpanjang umur simpan, meningkatkan nilai ekonomis dan penganekaragaman produk sehingga dapat meningkatkan pendapatan petani nanas.

Buah nanas selain dapat dikonsumsi dalam bentuk segar, dapat pula diolah lebih lanjut menjadi berbagai bentuk olahan antara lain: dodol nanas, buah kaleng, sirup, keripik nanas, selai dan lain sebagainya (Pracaya, 1982). Selai sendiri adalah jenis makanan olahan yang berasal dari sari buah atau buahbuahan yang sudah dihancurkan, ditambah gula dan dimasak sampai mengental. Selai tidak dikonsumsi secara langsung, melainkan digunakan sebagai bahan pelengkap pada roti tawar atau sebagai bahan pengisi pada roti manis, kue nastar atau kue kering, dan sebagai pemanis pada minuman seperti yogurt dan es krim (Lies, 2001).

Masyarakat Kabupaten Bolaang Mongondow pada umumnya bermata pencaharian sebagai petani, yang merupakan subsektor yang menjadi prioritas utama dalam mengembangkan dan meningkatkan kesejahteraan ekonomi para petani. Sebagian besar lahan pertanian diberdayakan oleh masyarakat untuk penanaman beberapa komoditas, khususnya komoditi hotikultura Nanas. Desa Lobong merupakan salah satu sentra produksi Nanas selain desa Wangga di Kabupaten Bolaang Mongondow Induk. Produksi Nanas di Desa Lobong sangat fluktuatif karena dipengaruhi musim. Sebagian besar produksi Nanas Bolaang Mongondow ini dipasok dari Desa Lobong.

Ada beberapa daerah yang sudah membuka usaha olahan buah nanas salah satunya di Kota Kotamobagu. Tak jauh dari desa lobong, tepatnya di jalan Veteran, kelurahan Motoboi Kecil terdapat Usaha kecil yang mempunyai nama selai Nanas "Cap Burung Maleo", Usaha tersebut milik seorang nenek yang bernama Hj.S. Hapulu Lubangon. Usaha selai nanas ini adalah usaha yang satusatunya ada di Kotamobagu. Seiring berjalannya waktu, usaha selai nanas "Cap Burung Maleo" semakin berkembang dan mulailah bermunculan produsen-produsen selai nanas sehingga terjadinya persaingan antar produsen selai nanas, namun usaha ini masih tetap bertahan dengan memiliki ciri khas tersendiri yaitu dengan memperkuat cita rasa produk dan cap burung maleonya yang menjadi andalannya.

Usaha selai nanas ini mempunyai kendala dalam stock bahan baku karena produk pertanian adalah musiman dan karenanya diperlukan manajemen stock yang baik, produk usaha pertanian bersifat local dan spesifik karenanya diperlukan perencanaan pengadaan bahan baku secara baik, harga produk pertanian umumnya berfluktuasi oleh karena itu diperlukan stock yang cukup agar tidak terjadi pembelian bahan baku yang berulang-ulang pada harga yang tidak pasti (Soekartawi, 1991). Usaha selai nanas ini berdiri pada tahun 2010 
dan terus berproduksi sampai dengan saat ini dan masih bisa bertahan dalam hal pengadaan bahan baku, manjemen, pemasaran serta laba perusahaan.

\section{Rumusan Masalah}

Berdasarkan uraian latar belakang yang dikemukakan, maka dapat dilihat bahwa masalah dalam penelitian ini adalah bagaimana pengadaan bahan baku, manajemen, pemasaran, serta laba dalam produksi selai nanas tersebut.

\section{Tujuan Penelitian}

Penelitian ini bertujuan untuk mendeskripsikan profil usaha selai nanas "Cap Burung Maleo UD. Asli Totabuan" dalam aspek pengadaaan bahan baku, manajamen, pemasaran, serta laba yang diperoleh dari usaha tersebut.

\section{Manfaat Penelitian}

1. Bagi penulis, mendapatkan ilmu yaitu aspek pengadaan bahan baku, manajemen, pemasaran, serta laba.

2. Bagi pemilik usaha, diharapkan dapat memberikan informasi bagi pemilik usaha selai nanas demi mengembangkan usahanya dan juga memberikan sedikit informasi tentang usaha tersebut.

\section{METODOLOGI PENELITIAN}

\section{Waktu Dan Tempat Penelitian}

Penelitian ini akan dilakukan pada industri kecil U.D Totabuan Cap Burung maleo di kelurahan motoboi kecil, Kotamobagu dengan waktu penelitian selama tiga bulan yaitu sejak April sampai dengan Juni 2016, mulai dari persiapan, pengumpulan data, sampai dengan penyusunan laporan hasil penelitian.

\section{Metode Pengumpulan Data}

Metode penelitian yang digunakan adalah studi kasus pada industri selai nanas "U.D Totabuan Cap Burung maleo". Pengumpulan data dilakukan dengan menggunakan data primer yang diperoleh melalui wawancara langsung dengan pemilik industri tersebut dengan menyebarkan kuisioner dan data data sekunder melihat pembukuan dari industri tersebut.

\section{Konsep Pengukuran Variabel}

1. Pengadaan bahan baku meliputi:

1. Harga Bahan Baku: harga beli buah nanas (Rp)

2. Bahan Baku: bahan dasar yang tersedia dan dipakai dalam proses produksi

3. Sumber pembelian bahan baku (dari petani ke perantara)

2. Manajemen adalah proses perencanaan, pengolahan, pengorganisasian, dan pengontrolan berbagai kegiatan dari suatu proses produksi dan pemasaran pada usaha U.D Totabuan.

3. Pemasaran yaitu teknik atau cara penyaluran produk dari produsen ke konsumen.

1. Mekanisme Pemasaran: proses penyaluran selai nanas dari produsen ke konsumen

2. Lokasi Pemasaran: tempat dimana produk pertama kali dipasarkan atau dijual.

4. Laba yaitu nilai yang diperoleh dari hasil penjualan dikurangi biaya yang dikeluarkan (Rp)

\section{Metode Analisis Data}

Analisis data yang digunakan dalam penelitian ini adalah analisis data secara deskriptif, dengan menggunakan data primer dan data sekunder, dimana data yang dikumpulkan dikaji dan dianalis secara deskriptif serta disajikan dalam bentuk tabel,

1. Untuk mengetahui besarnya biaya produksi yang dikeluarkan dari usaha tersebut (Soekartawi, 1995), rumus yang digunakan adalah:

2.

$$
T C=T V C+T F C
$$

$$
\begin{aligned}
& \text { Keterangan: } \\
& \text { TC : Total Cost } \\
& \text { TVC : Total Variabel Cost } \\
& \text { TFC : Total Fixed Cost }
\end{aligned}
$$

3. Untuk mengetahui laba yang diperoleh dari usaha tersebut menggunakan rumus (Soekartawi, 1995): 


\section{Keterangan:}

$$
\pi=\text { TR-TC }
$$

$\pi$ : Laba/Rugi

TR : Penerimaan Total

TC : Pengeluaran (Biaya Total)

* Jika L $=$ Negative berarti rugi

* Jika L $=$ Positif berarti laba untung

* Jika $\mathrm{L}=0$ berarti impas

Pendapatan merupakan hasil yang diterima melalui suatu usaha yang dinilai dengan hasil yang diterima melalui suatu usaha yang dinilai dengan uang atau barang atas penggunaan kekayaan atau jasa manusia.

4. Untuk mengetahui besarnya tingkat penerimaan digunakan rumus (Soekartawi, 1995):

$$
\mathbf{T R}=\mathbf{P} \cdot \mathbf{Q}
$$

Keterangan :

\section{HASIL DAN PEMBAHASAN}

\section{Deskripsi Umum UD Asli Totabuan Cap Burung} Maleo

Usaha selai nanas Cap Burung Maleo

UD Asli Totabuan dari Kotamobagu merupakan usaha yang berdiri sejak tahun 1975 yang bergerak di bidang pengolahan makanan seperti kue kolombeng, kacang goyang, kacang nougat bagea, namun pada tahun $2010 \mathrm{Hj}$. S. Hapulu Lubangon mencoba mengolah buah nanas untuk dijadikan selai nanas. Pengusaha ini mencoba berbagai metode pengolahan selai nanas agar sampai memperoleh kualitas selai nanas yang diisyaratkan yakni tahan lama, tanpa pengawet, dan tidak berjamur. Serta masih memiliki rasa dan tanpa kehilangan dan tanpa kehilangan rasa khas buah nanas. Usaha ini terdaftar pada Departemen Perdagangan dan Perindustrian dengan No PIRT/No/208. 7174. 01. 0052. 20. Usaha ini terletak di Kelurahan Motoboi Kecil Kecamatan Kotamobagu
TR (Total Revenue) : Total Penerimaan
$\mathrm{P}$ (Price) : Harga Produk
Q (Quantity) : : Jumlah Produk

5. Untuk mengetahui Break event Point (BEP) atau tiitik impas, menggunakan rumus (Mulyadi, 2001):

\section{BEP $($ dalam Rp $)=$ Biaya Tetap \\ 1- Biaya Variabel Harga jual \\ BEP $($ dalam per unit $)=\frac{F C}{P-V C}$}

6. Untuk mengetahui nilai penyusutan suatu barang menggunakan rumus:

$$
\begin{aligned}
& \mathbf{P}=\mathbf{N b}-\mathbf{N s} \\
& \mathbf{N} \\
& \text { Keterangan : } \\
& \mathrm{Nb}=\text { Nilai Baru/Nilai Beli } \\
& \mathrm{Ns}=\text { Nilai Sisa } \\
& \mathrm{N}=\text { Usia ekonomis (bulan) }
\end{aligned}
$$

Selatan. Selain lokasi ini merupakan pusat pengolahan dari produk-produk, usaha ini termasuk selai nanas juga merupakan tempat penjualan produk-produk, lokasinya sangat strategis berada di pinggir jalan raya, sehingga mudah dijangkau oleh konsumen.

\section{Pengadaan Bahan Baku}

Sumber bahan baku yang utama yang digunakan Usaha selai nanas ini yaitu buah nanas yang sudah masak, buah nanas ini banyak terdapat di Desa Passi Barat dan Lobong. Bahan baku diperoleh dari petani penghasil buah nanas di kedua desa tersebut. Pembelian buah nanas dilakukan ketika musim panen, dimana harga buah nanas berkisar Rp. 2500/gandeng, ketika tidak musim panen harga berkisar Rp. 10.000/gandeng, selain buah nanas untuk menghasilkan selai, selai nanas membutuhkan bahan penolong seperti gula pasir, gula pasir dibeli langsung dari Pasar ataupun Toko yang ada selain itu untuk pengemasan, digunakan toples plastic digunakan yakni 600 gram dan 400 gram, serta selotip sebagai perekat 
penutup toples, kedua bahan ini diperoleh/dibeli dipasar Kota Kotamobagu.

\section{Manajemen}

Usaha ini merupakan usaha keluarga, pemilik sekaligus melakukan fungsi manajerial dalam usaha ini, adapun fungsi manajamen yaitu perencanaan, pengarahan, pengawasan dilakukan secara mandiri oleh Pemilik dan kadangkala dibantu oleh anggota keluarganya.

1) Planning (perencanaan)

Pemilik usaha ini mengatur perencanaan dengan baik yaitu bisa mengatur pengadaan bahan baku pada saat kapan produk selai nanas sangat diperlukan konsumen dan tidak kehabisan stock selai nanas. membuat target penjualan setiap tahunnya apakah produk yang dipasarkan bisa bertambah konsumen atau mancari pelanggan baru.

2) Organizing (pengorganisasian)

Secara formal struktur organisasi yang ada di UD Totabuan adalah sebagai berikut:

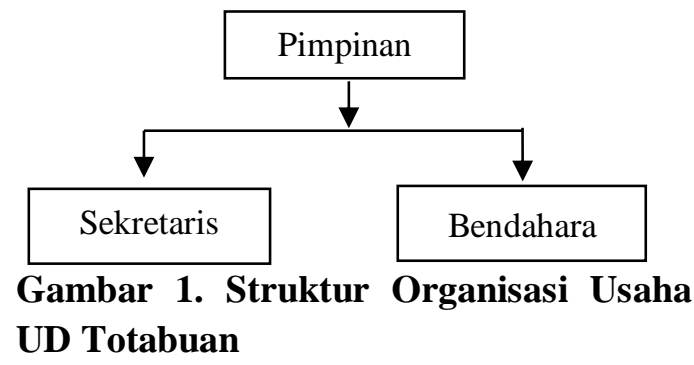

Organisasi ini bukan hanya untuk usaha selai nanas tapi juga berlaku untuk usaha lainnya. meskipun secara formal hanya memiliki struktur yang sederhana tetapi karena kerja keras dan keuletan Pemilik serta pengalaman yang dimilikinya mengakibatkan usaha ini berjalan dengan baik.

Di dalam usaha tersebut terdapat karyawan-karyawan yang disetiap melakukan pekerjaan terbagi menjadi beberapa bagian yaitu bagian pencucian, penggilingan, pengolahan, maupun pengemasan dan melaksanakan tgas-tugas sesuai dengan perintah atasan.

3) Actuating (pengarahan)
Setiap enam bulan satu kali pimpinan membuat meeting/rapat dengan karyawan agar supaya karyawan tersebut lebih terlatih atau mantap di dalam melakukan tugasnya masingmasing mengingat karyawan-karyawannya tidak semua mengenyam pendidikan/terbatas pendidikannya.

4) Controling (pengawasan)

Pada saat proses produksi mulai dari pengupasan sampai dengan pengemasan pimpinan selalu mengawasi para karyawannya, agar produk yang akan dipasarkan tidak membuat kecewa pelanggan atau konsumen jika ada yang mengalami kerusakan atau tidak sesuai dengan ketentuan.

\section{A) Proses Produksi}

UD Totabuan Cap Burung Maleo adalah salah satu usaha pengolahan selai nanas yang melakukan proses produksi tergantung musim. Buah nanas yang digunakan oleh UD Totabuan Cap Burung Maleo sebagai bahan baku selai nanas.

Dalam memproduksi selai nanas, alat yang digunakan sangat mudah didapat dan mudah dibeli seperti mesin penggilingan untuk proses penghalusan buah nanas, baskom untuk pencucian buah nanas setelah dikupas, wajan sebagai tempat pengolahan buah nanas, timbangan. Dibawah ini proses pengolahan selai nanas yang ada di UD Totabuan:

1. Pengupasan dan pencucian I

Nanas dikupas kulitnya, lalu daging buahnya dicuci sampai bersih.

2. Pencucian II

Nanas yang telah dikupas ditaruh pada tempat tersendiri (baskom/panci besar). Setelah semua nanas dikupas, lalu dibersihkan lagi dengan alat bersih.

3. Pengukusan

Setelah dilakukan pencucian nanas akan di kukus selama 2 jam.

4. Penggilingan

Giling nanas tersebut dengan mesin penggiling, hasil penggilingan ditampung dalam panci untuk diproses pada tahap berikutnya.

5. Pengolahan 
Panaskan nanas yang sudah di giling sampai mendidih, masukkan gula pasir sambil diaduk-aduk selama 5 jam. Setelah kental dan air yang terdapat di buah nanas benar-benar kering, lalu panci diangkat dari kompor.

6. Pengemasan

Masukkan selai nanas ke dalam toples yang sudah steril. Toples yang berisi selai nanas dikukus dalam air mendidih selama \pm 25 menit (toples dalam keadaan terbuka.

Dari hasil penelitian, usaha UD Totabuan melakukan proses produksi selai nanas tergantung musim.

\section{B) Produksi}

Produksi adalah hasil kegiatan atau aktivitas dari suatu perusahaan untuk memproses dan merubah bahan baku menjadi barang jadi melalui penggunaan tenaga kerja dan fasilitas produksi lainnya, dan proses pengolahan buah nanas menjadi selai nanas merupakan salah satu proses produksi, dimana bahan baku atau bahan mentah diubah menjadi bahan jadi yang dapat dikonsumsi oleh konsumen. jumlah dan nilai produksi yang dihasilkan dalam pengolahan selai nanas dapat dilihat pada tabel.

Dalam menentukan kemasan produksi, selera dan jumlah kebutuhan konsumen yang sangat beragam memberi pengaruh serta mendorong UD Totabuan Cap Burung Maleo untuk menyediakan kemasan produk yang beragam model kemasan.
Dari Tabel 1. dapat dilihat jumlah atau volume produksi untuk periode Maret jumlah produki yang dihasilkan untuk ukuran kemasan 600 gram yaitu sebesar 2.100 toples. Untuk kemasan 400 gram produksi sebesar 2.650 toples. Sedangkan untuk nilai produksi ukuran kemasan 600 gram bernilai 52.500.000, untuk ukuran kemasan 400 gram bernilai 63.600.000.

Harga kemasan untuk 600 gram yaitu Rp. 25.000 per toples dan kemasan 400 gram harganya Rp.24.000 per toples. Tabel I dapat juga dilihat untuk kemasan 600 gram produksi lebih banyak, hal ini dikarenakan selai nanas merupakan permintaan konsumen yang paling banyak. Sedangkan untuk kemasan 400 gramproduksi lebih sedikit diakrenakan selai nanas ini lebih kurang permintaan konsumen bila dibandingkan kemasan 600 gram.

\section{Pemasaran}

\section{a) Mekanisme Pemasaran}

Pemasaran merupakan proses penyaluran barang atau jasa dari pihak produsen ke pihak konsumen atau dengan kata lain pemasaran merupakan proses pemindahan barang dari produsen ke konsumen.

Mekanisme pemasaran produk selai nanas UD Totabuan Cap Burung Maleo yaitu salura pemasaran satu tingkat (a one level chanel) yaitu usaha selai nanas menjual produknya pada pedagang pengecer (toko dan swalayan) dengan harga yang telah ditetapkan oleh usaha selai nanas. Dari pedagang pengecer tersebut menjual produk tersebut ke konsumen.

Tabel 1. Model dan Ukuran Kemasan Selai Nanas UD Totabuan Cap Burung Maleo Periode Bulan Maret

\begin{tabular}{|c|c|c|c|c|}
\hline \multirow{2}{*}{$\begin{array}{l}\text { Periode } \\
(\text { minggu })\end{array}$} & \multicolumn{2}{|c|}{ Jumlah produksi (Toples) } & \multicolumn{2}{|c|}{ Nilai produksi (Rp) } \\
\hline & 600 gram & 400 gram & 600 gram & 400 gram \\
\hline 1 & 700 & 500 & 17.500 .000 & 12.000 .000 \\
\hline 2 & 400 & 700 & 10.000 .000 & 16.800 .000 \\
\hline 3 & 550 & 750 & 13.750 .000 & 18.000 .000 \\
\hline 4 & 450 & 700 & 11.250 .000 & 16.800 .000 \\
\hline Jumlah & 2.100 & 2.650 & 52.500 .000 & 63.600 .000 \\
\hline
\end{tabular}

Sumber: Data primer 2016, diolah 
Pada saat melakukan pendistribusian produk Usaha ini tidak melakukan jasa distributor melainkan pihak dari perusahaan sendiri yang mengantar ke tempat-tempat penjualan.

Secara skematis saluran pemasaran yang digunakan UD Totabuan dapat dilihat pada gambar berikut ini:

\section{b) Lokasi Pemasaran}

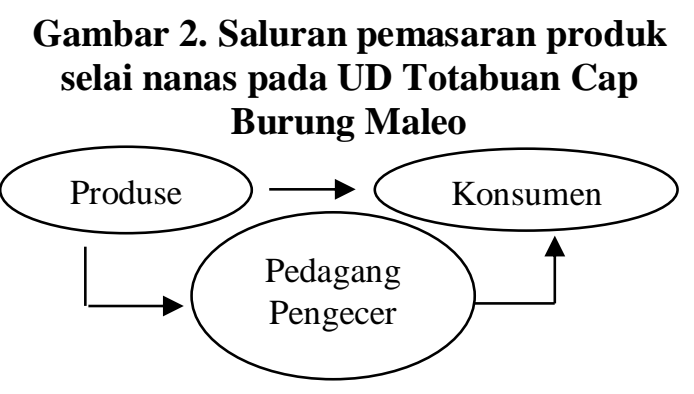

Saluran pemasaran produk yang dilalui oleh UD Totabuan Cap Burung Maleo meliputi dua saluran, yaitu:

1. Produsen ke konsumenPada saluran pemasaran yang pertama ini terjadi peasaran secara langsung, yaitu memasarkan produk

Laba

\section{Biaya}

\section{a) Biaya Produksi}

secara langsung digunakan dalam produksi selai nanas yaitu buah nanas. Biaya produksi adalah biaya yang dikeluarkan didalam suatu kegiatan industri untuk memproses dan mengubah bahan baku berupa buah nanas menjadi selai nanas melalui penggunaan tenaga kerja dan fasilitas produksi lainnya. biaya produksi sendiri harus

\section{Biaya Bahan Baku}

Produk yang dihasilkan dari suatu perusahaan atau industri akan tercipta karena adanya persediaan bahan baku. Bahan baku merupakan faktor penting terhadap kualitas akhir barang jadi, oleh karea itu kualitas suatu bahan baku merupakan pertimbangan utama dalam pembeliaan bahan baku.
Perusahaan UD Totabuan Cap Burung Maleo memiliki jangkauan pemasaran yang cukup luas. Produk pertama kali dipasarkan hanya di Toko-Toko di sekitar Kotamobagu, saat ini wilayah pemasaran semakin berkembang meliputi Kota Manado, Gorontalo, Tomohon, Bitung dan Amurang. Sistem pembayaran yang diberlakukan oleh UD Totabuan yaitu setiap minggu sesuai dengan jumlah produk yang terjual di Toko tersebut.

secara langsung ke konsumen tanpa melalui perantara. Dalam saluran ini konsumen bisa secara langsung mendatangi perusahaan UD Totabuan Cap Burung Maleo di lokasi untuk membeli produk.

2. Produsen ke Pedagang Pengecer ke Konsumen

Pada saluran pemasaran ini terjadi proses pemasaran secara tidak langsung, dimana dalam pendistribusian selai nanas UD Totabuan Cap Burung Maleo akan memasarkan produk nya ke pedagang pengecer sebagai distributor terlebih dahulu dan kemudian akan dijual ke konsumen akhir

Biaya produksi meliputi semua pengeluaran usaha untuk menghasilkan produk olahan selai nanas atau biaya yang dikeluarkan oleh perusahaan untuk menghasilkan suatu barang biaya produksi yang dimaksud adalah biaya bahan baku langsung yaitu biaya bagi bahan

mengetahui biaya tetap dan biaya variabel. Dengan mengetahui biaya tetap dan biaya variabel, maka biaya produksi dapat dihitung berdasarkan penjumlahan antara biaya tetap dan biaya variabel. Berikut perhitungan biaya produksi usaha:

Untuk mendapatkan bahan baku selai nanas yaitu berupa buah nanas, usaha ini membeli buah nanas dari petani buah nanas yang berada di desa Lobong, sehingga kebutuhan akan bahan baku selalu tersedia.

Pembuatan selai nanas memerlukan bahan baku utama/langsung yaitu buah nanas. Penggunaan bahan baku dalam setiap minggu jumlah bahan baku yang digunakan berbeda- 
Tabel 3. BOP Usaha UD. Totabuan Cap Burung Maleo Periode Maret

\begin{tabular}{|c|c|c|c|}
\hline${ }^{\mathbf{N}}$ & $\begin{array}{l}\text { Jenis } \\
\text { Biaya }\end{array}$ & Uraian & Biaya Produksi (Rp) \\
\hline 1 & $\begin{array}{c}\text { Biaya } \\
\text { Overhead } \\
\text { Pabrik } \\
(\mathrm{BOP})\end{array}$ & $\begin{array}{ll}\text { - } & \text { Biaya bahan baku tidak langsung/penolong } \\
\text { - } & \text { Biaya listrik } \\
\text { - } & \text { Biaya transportasi } \\
\text { - } & \text { Biaya pajak } \\
\text { - } & \text { Biaya penyusutan } \\
\text { - } & \text { Biaya pengemasan }\end{array}$ & $\begin{array}{l}280.000 \\
1.000 .000 \\
1.000 .000 \\
150.000 \\
172.938,735 \\
12.803 .750\end{array}$ \\
\hline
\end{tabular}

Sumber: Data primer 2016, diolah

beda yaitu antara 5-10 kg buah nanas di timbang setelah menjadi olahan selai nanas. Ketersediaan bahan baku disetiap periodenya berbeda disebabkan jumlah buah nanas yang di panen petani nanas tidak selalu ada.

\section{Biaya Tenaga Kerja}

Biaya tenaga kerja tidak langsung merupakan harga yang dibayarkan untuk penggunaan sumber daya manusia. Biaya tenaga kerja ada yang bersifat langsung dan tidak langsung. Berikut ini akan diuraikan biaya tenaga kerja langsung.

Tabel 2 menunjukkan penggunaan tenaga kerja disetiap produksi perorang perharinya Rp. 50.000. jadi disetiap bulannya usaha ini mengeluarkan upah tenaga kerja sebesar Rp. 1.750.000. tenaga kerja banyak dipakai pada saat jumlah buah nanas sangat banyak untuk diproduksi, pada saat hanya pengemasan hanya membutuhkan satu sampai dua orang saja

\section{Biaya Overhead Pabrik}

\section{Biaya Bahan Tidak Langsung/Penolong}

Bahan tidak langsung atau bahan penolong adalah mencakup semua bahan lain yang dipakai dalam proses produksi. Bahan penolong yang digunakan yaitu hanya gula

Pada Tabel 4 menunjukkan bahwa penggunaan bahan penolong atau bahan tidak langsung periode Maret yaitu gula pasir sebesar $20 \mathrm{~kg}$ dengan hargal kg gula pasir Rp. 14.000, pembuatan selai nanas hanya membutuhkan bahan penolong yaitu gula pasir, jadi besarnya
Tabel 2. Penggunaan Tenaga Kerja

Langsung Selama Bulan Maret

\begin{tabular}{ccc}
\hline $\begin{array}{c}\text { Periode } \\
\text { (minggu) }\end{array}$ & $\begin{array}{c}\text { Tenaga } \\
\text { Kerja } \\
\text { Langsung } \\
\text { (per orang) }\end{array}$ & Upah $(\mathbf{R p )}$ \\
1 & 7 & 350.000 \\
2 & 10 & 500.000 \\
3 & 8 & 400.000 \\
4 & 10 & 500.000 \\
\hline Jumlah & 35 & 1.750 .000 \\
\hline
\end{tabular}

Sumber: Data Primer 2016, diolah

Biaya Overhead Pabrik (BOP) merupakan biaya manufaktur yang tidak termasuk pada biaya bahan baku langsung. Pada Tabel 3 dapat dilihat rincian BOP dari usaha UD. Totabuan Cap Burung Maleo untuk periode Ma Pada Tabel 3 dapat dilihat bahwa BOP dari usaha UD Totabuan Cap Burung Maleo sebesar Rp. 15.406.688,735. Berikut akan diuraikan masing-masing biaya yang $\begin{array}{lll}\text { termasuk } & \text { pada }\end{array}$

pasir. Sebelum buah nanas menjadi produk nanas, buah selai nanas dipanaskan dan dicampur dengan gula pasir sambil diaduk-aduk sampai mengantal . Untuk $5 \mathrm{~kg}$ buah

biaya bahan penolong yaitu sebesar Rp. 280.000,

\section{a. Biaya Listrik}

Biaya listrik yang dikeluarkan oleh industri untuk produk selai nanas periode Maret 
sebesar Rp.1.000.000. biaya listrik yang digunakan yaitu biaya listrik pada lampu, karena untuk menerangi pada waktu proses produksi dan proses pembuatan selai nanas dibutuhkan waktu 6 jam. membeli bahan bakar untuk transportasi yaitu sebesar Rp. 500.000.

\section{c. Biaya Pajak}

Biaya pajak usaha per tahun yang Tabel 4. Penggunaan Bahan Baku Tidak Langsung Selama Periode Maret

\begin{tabular}{cccc}
\hline $\begin{array}{c}\text { Periode } \\
(\mathbf{m i n g g u})\end{array}$ & & Gula \\
\hline & $\begin{array}{c}\text { Jumla } \\
\text { h (kg) }\end{array}$ & Nilai & Jumlah \\
& & \\
$\mathbf{1}$ & 5 & 14000 & 70.000 \\
$\mathbf{2}$ & 5 & 14000 & 70.000 \\
$\mathbf{3}$ & 5 & 14000 & 70.000 \\
$\mathbf{4}$ & 5 & 14000 & 70.000 \\
\hline Jumlah & 20 & & 280.000 \\
\hline
\end{tabular}

\section{b. Biaya Transportasi}

Biaya pemasaran merupakan biaya transportasi yang digunakan memasarkan produk selai nanas. Berdasarkan informasi yang diperoleh dari pemilik perusahaan, pengeluaran

Dalam proses produksi selai nanas menggunakan beberapa jenis alat. Alat-alat tersebut merupakan modal tetap industri UD Totabuan Cap Burung Maleo dalam mengolah dikeluarkan pada industri ini adalah sebesar Rp. 1.800 .000 ,. dan pajak per bulannya yaitu sebesar Rp. 150.000,

\section{d. Penyusutan}

buah nanas. Peralatan-peralatan ini mengalammi penyusutan seiring dengan lamanya pemakaian. Pada Tabel 5 dapat dilihat jenis dan nilai modal tetap serta penyusutannya.

Tabel 5 Jenis dan Nilai Modal Tetap Serta Penyusutan Pada Industri UD Totabuan Cap Burung

\section{Maleo}

\begin{tabular}{|c|c|c|c|c|c|c|}
\hline No & Jenis & $\begin{array}{l}\text { Jumlah } \\
\text { (unit) }\end{array}$ & $\begin{array}{l}\text { Harga Beli } \\
\text { (Rp) }\end{array}$ & $\begin{array}{c}\text { Umur } \\
\text { Ekonomis } \\
\text { (Bulan) }\end{array}$ & Nilai Sisa (Rp) & $\begin{array}{c}\text { Nilai } \\
\text { Penyusutan } \\
\text { (Rp) }\end{array}$ \\
\hline 1 & Baskom & 10 & 1.000 .000 & 60 & 500.000 & 840 \\
\hline 2 & Timbangan & 2 & 600.000 & 492 & 300.000 & 608 \\
\hline 3 & Pisau & 5 & 50.000 & 60 & 41.000 & 150 \\
\hline 4 & $\begin{array}{l}\text { Tong } \\
\text { penyimpanan }\end{array}$ & 50 & 10.000 .000 & 60 & 8.000 .000 & 33,335 \\
\hline 5 & Wajan & 22 & 11.000 .000 & 36 & 5.500 .000 & 152.779 \\
\hline 6 & Kompor & 10 & 3.000 .000 & 36 & 1.500 .000 & $41.66,7$ \\
\hline 7 & Sondo kayu & 4 & 160.000 & 24 & 82.000 & 3.250 \\
\hline 8 & Penggilingan & 1 & 500.000 & 60 & 250.000 & $4.166,7$ \\
\hline 9 & $\begin{array}{l}\text { Tabung Gas } \\
\text { Jumlah }\end{array}$ & 10 & $\begin{array}{l}1.250 .000 \\
27.560 .000\end{array}$ & 36 & 1.0000 .000 & $\begin{array}{r}6.945 \\
172.938,735\end{array}$ \\
\hline
\end{tabular}

Sumber: Data primer 2016, diolah

Pada Tabel 5 menunjukkan bahwa modal tetap sebesar Rp. 27.560.000,. dan total penyusutan sebesar Rp. 172.938,735. jenis modal ntuk kendaraan dibagi dua karena digunkan untuk usaha dan keluarga. Besarnya nilai sisa ditaksir secara kasar berdasarkan hasil survei dan perhitungan secara nominal sehingga nilai sisa relatif tinggi.
Rumus Penyusutan $=\frac{\text { Harga beli-nilai sisa }}{\text { umur ekonomis }}$

\section{e. Biaya Pengemasan}

Biaya pengemasan atau biaya perlengkapan yaitu biaya untuk membeli toples kemasan selai nanas. Berikut perinciannya pada Tabel 6. Pada Tabel 6 menunjukkan bahwa biaya kemasa yaitu biaya pembelian toples dan selotip pada 
periode bulan maret sebesar Rp. 12.803.750. dimana dalam 1 hari UD Totabuan melakukan pengemasan selai nanas sebesar 100 toples per harinya, sedangkan harga satu toplesnya ukuran 600 gram yaitu Rp.2500 dan harga satu toples ukuran 400 gram seharga Rp.2000. Sedangkan satu buah selotip bisa digunakan untuk 50 toples (600 gram) dan 80 toples (400 gram) dengan harga satu buah selotip seharga $\mathrm{Rp}$. 3000 . Maka jumlah kemasan yang digunakan UD Totabuan pada periode maret sebanyak 4750 toples.

Tabel 6 Biaya Pengemasan Selama Periode Bulan Maret 2016

\begin{tabular}{llr}
$\begin{array}{c}\text { Periode } \\
\text { (Minggu) }\end{array}$ & \multicolumn{2}{c}{ Biaya Pengemasan } \\
& $(600 \mathrm{gr})$ & $(400 \mathrm{gr})$ \\
$\mathbf{1}$ & 2.170 .000 & 1.187 .500 \\
$\mathbf{2}$ & 1.240 .000 & 1.662 .500 \\
$\mathbf{3}$ & 1.705 .000 & 1.781 .250 \\
$\mathbf{4}$ & & \\
& 1.395 .000 & 1.662 .500 \\
\hline Jumlah & 6.510 .000 & 6.293 .750
\end{tabular}

Sumber: Data primer 2016, diolah

\section{B) Penerimaan}

Penerimaan merupakan suatu hasil yang diterima oleh perusahaan setelah menjual produknya kepada konsumen akhir. Penerimaan adalah hasil yang diperoleh dari jumlah produksi dikali dengan harga jual. Berikut ini perhitungan penerimaan dari usaha selai nanas:
$\mathrm{TR}=\mathrm{P} \cdot \mathrm{Q}$

Kemasan Ukuran 600 gram:

$=2.100 \times$ Rp. 25.000

$=\mathrm{Rp} .52 .500 .000$

Kemasan Ukuran 400 gram:

$=2.650$ X Rp. 24000

$=$ Rp.63.600.000

Total penerimaan

$=$ Rp. 116.100 .000

\section{C) Keuntungan}

Besar keuntungan yang diterima oleh industri tergantung pada penerimaan dan pengeluaran yang di dalam industri itu sendiri. Penerimaan sangat tergantung pada harga jual produk yang telah ditetapkan oleh industri, sedangkan pengeluaran yang terjadi dalam industri berhubungan dengan biaya produksi. Penerimaan dapat diperoleh dari hasil perkalian antara harga jual produk dengan jumlah produksi. Dengan mengetahui penerimaan dengan pengeluaran, maka keuntungan dapat dihitung berdasarkan pengurangan antara jumlah penerimaan dan jumlah pengeluaran. Berikut perhitungan keuntungan usaha:

$$
\begin{aligned}
& \pi=T R-T C \\
& \pi=\text { Rp. } 116.100 .000-\text { Rp. } 106.474 .172 \\
& \pi=\text { Rp. } 9.625 .828
\end{aligned}
$$

Dari hasil yang didapat bahwa total keuntungan yang diperoleh usaha selai nanas UD Totabuan Cap Burung Maleo pada kemasan 600 gram dan 400 gram adalah Rp. 9.625.828 Total biaya produksi sebesar Rp. 106.474.172 dimana produk ini dijual dengan harga Rp. 25.000 untuk kemasan toples ukuran 600 gram dan Rp. 24.000 untuk kemasan toples ukuran 400 gram.

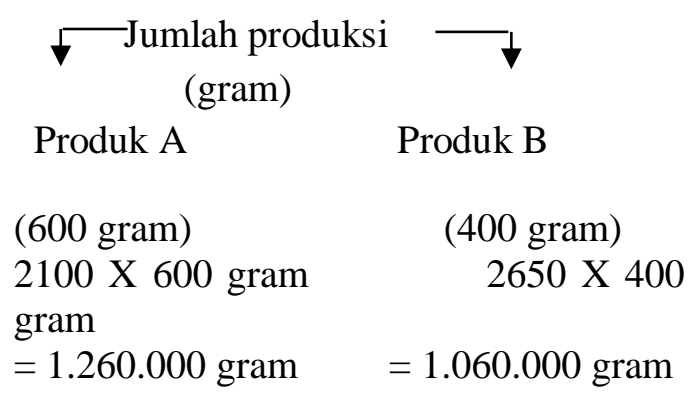




\section{D) Analisis Titik Impas}

Jumlah produksi:

$=$ Produk A + Produk $\mathrm{B}$

$=1.260 .000+1.060 .000$

$=2.320 .000$

Gram:

= Biaya Variabel/ Total Produksi (gram)

$=106.474 .172 / 2.320 .000$

$=46$ gram

46 X 600 gram:

$=28.000 /$ toples

Harga pertoples 600 gram:

$=28.000$

700 toples $->\mathrm{BV}$ :

$=28.000 \times 700$

$=19.600 .000$

Break even point (BEP) dapat diartikan sebagai bahan pertimbangan jumlah produk minimal yang dihasilkan agar perusahaan tidak mengalamin kerugian. Menurut Muyadi (2001), BEP merupakan keadaan dimana perusahaan tidak mengalami untung atau rugi. Rata-rata BEP (dalam Rp) adalah Rp. 1.921.534 dan rata-rata BEP (dalam unit) adalah 7,6 unit (600 gram), 8,1 unit (400 gram), usaha selai nanas pada titik break event point tidak menguntung dan tidak merugi.

\section{KESIMPULAN DAN SARAN}

\section{Kesimpulan}

Melalui hasil penelitian yang sudah dilakukan pada usaha selai nanas UD. Totabuan Cap Burung Maleo dapat disimpulkan:

1. Usaha selai Nanas Cap Burung Maleo UD. Asli Totabuan hanya satu tahun satu kali dalam melakukan produksi selai Nanas, bahan baku yang digunakan yaitu buah nanas yang diperoleh dari petani yang ada di Passi Barat dan Lobong.

2. Usaha ini merupakan usaha keluarga, pemilik sekaligus melakukan fungsi manajerial dalam usaha ini, perencanaan, pengarahan, pengawasan dilakukan secara mandiri oleh Pemilik dan kadangkala dibantu oleh anggota keluarganya

3. Saluran pemasaran yang dilalui UD. Asli Totabuan meliputi dua saluran yaitu Produsen ke konsumen dan Produsen ke Pedagang Pengecer ke Konsumen

4. Laba yang diperoleh .usaha selai Nanas UD. Totabuan Cap Burung Maleo untuk bulan Maret 2016 sebesar Rp. 9.625.828

\section{Saran}

Pemerintah lebih memperhatikan usaha-usaha kecil seperti Usaha selai nanas UD Totabuan Cap Burung Maleo yang sangat membutuhkan peralatan pengemasan agar produk terjaga dari jamur, menciptakan suasana lingkungan kerja yang dinamis dan Perlu adanya pembukuan dari industri sendiri agar dapat diketahui berapa keuntungan yang di dapat setiap satu kali produksi. 


\section{DAFTAR PUSTAKA}

Abidjulu, R. (060314025). Profil usaha "Nasi kuning" di Kecamatan Tuminting Kota Manado. Manado: Fakultas Pertanian Jurusan Sosial Ekonomi UNSRAT.

Adam, L (030314017). 2006. Profil Usaha kecil "U.D. Putri" di Kelurahan Wangurer Timur

Kec. Bitung Tengah. Manado: Fakultas Pertanian Jurusan Sosial Ekonomi UNSRAT.

Adi, K. 2007. Analisis usaha kecil dan menengah. Yogyakarta: Penerbit CV. Andi Offset.

Amin, R. 2012. Tingkat Produktivitas tenaga kerja sektor pertanian di SULUT. Manado: Fakultas Pertanian jurusan sosial ekonomi UNSRAT.

Anonim, 19995. Undang-undang No 9 Tahun 1995 Tentang usaha kecil. Bank Indonesia: Jakarta.

Astuti, D. 2015. Kajian Bisnis franchise makan di Indonesia. Jurnal manajemen dan kewirausahaan, vol. 7. No. 1.

Harta, S. 2012. Pembibitan Tanaman Buah mudah, murah dan hasil melimpah. Klaten: Bintang Publishing.

Jusup. 2002. Manajemen Produksi. Yogyakarta: STIE YKPN.

Kotler., P. 2004. Manajemen pemasaran, analisis, perencanaan, implementasi, dan control. Edisi sebelas. Jakarta: PT. Prenhallindo.

Lies, MS. 2001. Membuat aneka olahan nanas. Jakarta: Puspa Swara.

Manullang, M. 1991. Pengantar Ekonomi Perusahaan. Yogyakarta: Penerbit Liberty.

Miarso. 2007. Menyemai benih teknologi pendidikan. Jakarta: Pustekom Dinas.

Mulyadi, 2001. Akuntansi Manajemen, konsep, manfaat, dan rekayasa. Jakarta: Salemba Empat.
Nayla, R. 2014. Komplet akuntansi untuk UKM dan waralaba. Jogjakarta: Laksana.

Pracaya. 1982. Bertanam Nanas. Jakarta: PT. Penebar Swadaya.

Primiana, I. 2009. Menggerakkan sektor riil UKM dan Industri. Bandung: Penerbit Alfabeta.

Rantung, D. 2014. Jurnal EMBA penerapan biaya diferensial dalam pengambilan keputusan membeli/memproduksi sendiri pada R.M. pangsit Tompaso. Vol. 2. No. 3 hal 32. Manado: Fakultas Ekonomi Dan Bisnis Jurusan Akuntansi UNSRAT.

Samadi, B. 2014. Panen untung dari budidaya nanas sistem organik. Yogyakarta: Lily publisher.

Soekartawi, 1991. Pengantar Agroindustri. Jakarta: PT. Raja Grafindo Persada.

Soekartawi, 1995. Analisis Usaha Tani. Jakarta: UI Press.

Suhartanti, R. Skripsi Anlaisis Pengendalian Bahan Baku Minuman Bandrek Pada CV. Cihanjuang Inti Teknik. Jakarta:

Sunarjono, H. 2015. Berkebun 26 jenis tanaman buah. Jakarta: penebar swadaya.

Sunjaja, Ridwan, dan Inge Berlian. 2003. Manajemen Keuangan 2. Yogyakarta: Edisi Keempat Literata Lintas Media.

Tohar, M. 2001. Membuka usaha kecil. Yogyakarta: penerbit kanisius.

Winardi. 1994. Pengantar ekonomi pembangunan. Bandung: Tarsito. 